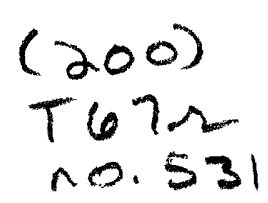

Geology and Mineralogy

This document consists of 42 pages, plus 1 figure.

Series A

DNITED STATES DEPARTMENT OF THE INTERIOR

GEOLOGICAL SURVEY

SELECTED ANNOTATED BIBLIOGRAPHY AND INDEX MAP OF THORIUM AND RARE-EARTH DEPOSITS IN THE UNITED STATES AND ALASKA*

By

Katharine L。 Buck

July 1955

'TraceiElements Investigations Report 531

This preliminary report is distributed without editorial and technical review for conformity with official standards

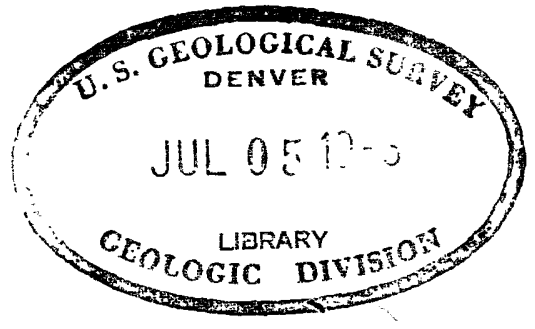
and nomenclature. It is not for public inspection or quotation.

* *This report concerns work done on behalf of the Division of Raw Materials of the U. S. Atomic Energy Commission. 
U. S. Geologícal Survey :

Alaskan Geology Branch, Menlo Park . . . . . . . . . . 2

Fuels Branch, Washington。 . . . . . . . . . . . . . . . . . 1

Geochemistry and Petrolagy Branch, Washington . . . . . . . . . . 1

Geophysics Branch, Washington 。. . . . . . . . . . . . . . 1

Mineral Deposits Branch, Washington . . . . . . . . . . . 2

P. C. Batemañ, Menlo Park 。 . . . . . . . . . . . . . . . 1

A. L. Brokaw。 Grand Junction . . . . . . - . . . . . . . . . 1

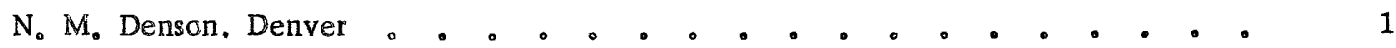

C. E. Dutton, Miadison . . . . . . . . . . . . . . . . . . 1

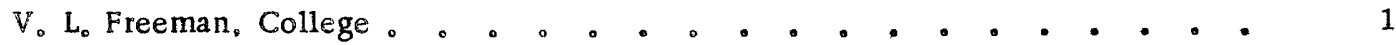

R. Lo Griggs, Albuquerque . . . . . . . . . . . . . . . . . 1

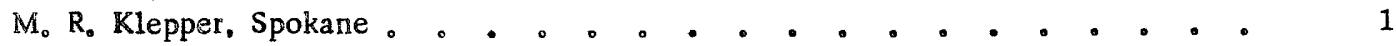

A。 Hoschmann。 Denver . . . . . . . . . . . . . . . . 2

R. A. Laurence, Knoxville 。 . . . . . . . . . . . . . . 1

Jo $\mathrm{D}_{\mathrm{o}}$ Love Laramie 。 . . . . . . . . . . . . . . . . . 1

L. R. Page, Washingron 。 . . . . . . . . . . . . . . . . 1

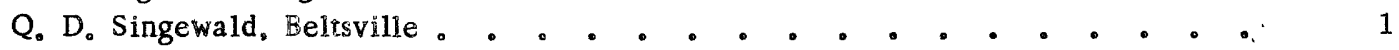

A. E。 Weissenborn, Spokane 。 . . . . . . . . . . . . . . . . 1

TEPCO, Denver . . . . . . . . . . . . . . . . . . 5

TEPCO, RPS, Washington, (including master) . . . . . . . . . . . . 2 


\section{CONTENTS}

Page

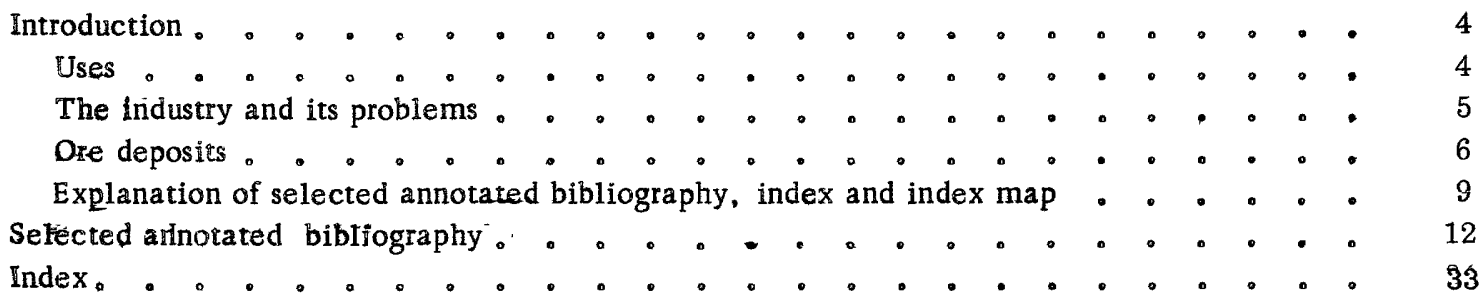

ILLUSTRATIONS

Figure 1. Index map of thorium and rare-earth deposits in the United States...$^{-}$. In envelope

2. Index map of thorium and rare-earth deposits in Alaska $. . . \quad . \quad . \quad . \quad 10$ 


\title{
SELECTED ANNOTATED BIBLIOGRAPHY AND INDEX MAP OF THORIUM AND RARE - EARTH DEPOSITS IN THE UNITED STATES AND ALASKA
}

\author{
By Katharine I. Buck
}

\section{INTRODUCTION}

Thorium and rare-earth metals have come into strategic importance in this country in the last few years with the potential use of thorium in the production of atomic power and the development of new uses for the rare earths in the aircraft industry. The United States was thought to be dependent upon foreign sources of these elements because its entire supply from 1910 to 1950 was imported, principally from India and Brazil. By 1951 the foreign supplies of monazite, the main ore of thorium and the rare earths, were cut aff because of restrictions imposed by the producing countries on the exportation of fissionable materials and their ores. It then became necessary for the United States to develop sources of these elements within its own borders, and a concerted search has led to the discovery of reserves sufficient for current demands and resources sufficient for increased demands if the economic situation were altered by an increased price for the ore minerals or by an increased market for the byproduct minerals of monazite production (Congressional Documents, 1953, p6 211-219).

The rare-earth metals are the elements ranging in atomic number from 57 to 71 and include lanthanum, cerium, praseodymium, neodymium, promethium, samarium, europium, gadolinium, terbium, dysprosium, holmium, erbium, thulium, ytterbium, and lutecium. Yttrium, atomic number 39, and scandium, atomic number 21 , occur almost inseparably with the rare earths proper and are usually included in the group. Thorium, atomic number 90 , also occurs with the rare earths in nature.

\section{Uses}

The principal early use of rare earths and thorium was in the manufacture of incandescent gas mantles. Monazite was mined in the United States for this purpose from the 1890's until 1911, when the tungsten lamp largely replaced the gas mantle. The manufacture of gas mantles is, however, still the main use of thorium, 
although the amount consumed in such manufacture is decreasing. Thorium is now used in the filaments of tungsten lamps, in radio tubes, in refractories, and in the chemical and medical industries, Pure thorium has recently been produced for experimental purposes and would probably have industrial application if it were in sufficient supply (Congressional Documents, 1952, $\mathrm{p}, 112-113$ ). The use of thorium in the manufacture of nuclear power is now in the planning stage (U. $S$. Atomic Energy Commission, 1954, p。25) and takes precedence over the development of other new uses.

The rare earths are more widely used than thorium in industry. Cerium compounds are used in the carbon arc electrode cores of searchlights and motion picture projectors. Mischmetal, a mixture of rare earths, is used in the sparking elements of cigarette lighters and, alloyed with copper, nickel, zinc。 aluminum and magnesium, in aircraft parts, gas turbines, and jet engines. Some of the rare earths are used it waterproofing, mothproofing, and mildewproofing fabrics, in printing and dyeing and in the glass industry as coloring agents, polishing agents, and in the manufacture of certain special purpose glasses.

The industry and its problems

The main ore mineral of thorium and the rare earths, monazite, occurs primarily in beach and river placer concentrations. In this country domestic placers have been mined for their monazite content alone only in the last five years and in the period 1893-1911. The monazite produced between the two periods mentioned has been a byproduct: of the mining of other minerals, such as ilmenite or gold, and even now the economics of producing monazite are complicated by the problem of marketing the byproduct minerals in order to reduce the overall cost of mining.

Large deposits of bastnaesite, which recently have been discovered and may become the main source of rare earths in this country, interject another factor into the economics of production and use of rare earths and thorium. Bastnaesite contains an amount of thorium that is insignificant at current prices so that if bastnaesite, instead of monazite, were to dominate as the rare-earth ore, byproduct production of thorium would drop considerably. 
There is a ready market for rare earths in this country, but domestic mining operations are ingecure in view of the threat of the return of foreign imports which would place the price below the domestic cos: of mining. The profitable mining of monazite is dependent on the market for byproduct heavy minerals, as stated above. This factor is especially important in the Idaho field. The market for thorium as such is extremely limited. Thorium is purchased in the mineral monazite which is sold for and graded on its combined rare-earth and thorium content.

$$
\text { Ore deposits }
$$

Monazite is the principal ore mineral of both thorium and the rare earths. In this country, thorite is an important potential ore mineral of thorium, and bastnaesite is an important ore mineral of the rare earths. Monazite is essentially a phosphate of cerium and lanthanum and contains small variable quantities of the other rare earths, thorium, silicon, uranium and other elements. It usually contains from a few percent to 10.6 percent thorium. Minable monazite deposits are found generally in placers, but monazire also occurs as an accessory mineral in many granitic rocks, which are the ultimate source of the placer concentrations. Commercial monazite contains from 55 to 65 percent total rare-earth oxides plus thoria.

Thorite is a silicate of thorium and contains from 25.2 to 62.7 percent thorium and up to 9.0 percent uranium. Thorite or a hydrated thorite-like mineral is the main ore mineral of some of the vein deposits recently discovered in this country, notably those in the Westcliffe and Powderhorn districts of Colorado and the Lemhi Pass district of Idaho, and it occurs along with bastnaesite in similar deposits in the Mountain Pass district of California .

Bastnaesite was a mineralogical curiosity until early in this decade when a large bastnaesite-barite deposit was discovered at Mountain Pass, Calif。, and production began from a bastnaesite-fluorite deposit in the Gallinas Mountains of New Mexico. Bastnaesite is a fluocarbonate of the rare earths, primarily cerium and lanthanum, and contains less than one percent uranium and thorium. 
Monazite is now being produced in the United States from the placers of the central Idaho region (Anonymous, 1949a, 1950a, 1952b,1954b, 1954e) and the Jacksonville, Fla 。 placer deposit of the National Lead Company (Mertie, 1953, fo 15\% Monazite is produced from the Jacksonville deposit as a byproduct of ilmenite mining. Monazite was mined from western North and South Carolina stream placers in the late nineteenth and early twentieth centuries for use in gas mantles. It has also been produced from a beach placer near Mineral City, Fla (Santmyers, 1930, p。11), and as a byproduct of the Climax molybdenum deposit of the Tenmile district, Colo. (Carlson, Kaufman, and others, 1953, p. 11). Potential regions of monazite production are the drainage areas of the Idaho batholith in Idaho and Montana, the drainage areas of the western and eastern monazite belts of the southeastern states as outlined by Mertie (1953, p. 15, 24-30), and the drainage areas of the Tuscaloosa formation of the southeastern states (Mertie, 1953). Other districts which may produce thorium and the rare earths from monazite are the Mineral Hill district, Idaho and Mont., where monazite and allanite occur in marble layers in Precambrian metamorphic rocks, and the Palmer area, Marquette County, Mich, , where monazite occurs in ancient placers of the Upper Huronian Goodrich quartzite. Monazite may also contribute to the radioactivity of the beach sands of the southeastern Atlantic and Gulf coasts, and it is possible that a commercial deposit may be found in such sands (Anonymous, 1954a, 1954d)。

No mines in this country are producing thorite or thorogummite (hydrothorite) at the present time. However, the Westcliffe and Powderhorn districts of Colorado (Christman and others, 1953; Burbank and Pierson, 1953, p。2,3) and the Lemhi Pass district of Idaho (Trites and Tooker, 1953, p. 191-205) are potential sources of thorite or thorogummite. Thorium occurs in thorogummite, $\left(T h_{6} U\right) S_{4} \mathrm{O}_{4} \cdot 6 \mathrm{H}_{2} \mathrm{O}$, and thorium-bearing zircon in the Wausau area,Wis.

Bastnaesite is currently being produced from the Mountain Pass district, Calif. (Carlson, Keiser and Sargent, 1953; Olson and others, 1954), and the Gailinas Mountains district of New Mexico (Anonymous, 1952a). No other potential producers of bastraesite are known in this country at the present time. 
The Baringer Hill district, Llano County, Tex., produced, in the early $1900^{\circ}$ s, a few hundred pounds of rare earths a year,from a pegmatite intruded into Precambrian granite. The principal rare earthbearing minerals mined were gadolinite, $\mathrm{Be}_{2} \mathrm{FeY}_{4} \mathrm{Si}_{2} \mathrm{O}_{13}$; allanite, (Ca, Ce, Th) ${ }_{2}\left(\mathrm{Al}, \mathrm{Fe}, \mathrm{Mg}_{3} \mathrm{Si}_{3} \mathrm{O}_{12}(\mathrm{OH})\right.$; cyrtolite, an altered zircon containing wranium, thorium,yttrium and other rare earths; fergusonite, $(\mathrm{Y}, \mathrm{Er}, \mathrm{Ce}, \mathrm{Fe})(\mathrm{Nb}, \mathrm{Ta}, \mathrm{Ti}) \mathrm{O}_{4}$; and polycrase $(\mathrm{Y}, \mathrm{Ca}, \mathrm{Ce}, \mathrm{U}, \mathrm{Th})(\mathrm{Ti}, \mathrm{Nb}, \mathrm{Ta})_{2} \mathrm{O}_{6}(\mathrm{Hess}, 1908)$ 。 Potential areas of production of rare earths and thorium from minerals other than monazite, thorite, or bastnaesite are the Bear Lodge Mountains district, Wyo. . where the thorium-, rare earth-bearing minerals have not yet been identified; the Mineville district of New York where rare earths and thorium occur in fluorapatite and might be recovered as a byproduct of magnetite mining; and the St. Peters Dome district. E1 Paso County. Colo., where several rare earth-riand thorium-bearing minerals occur in pegmatites.

There are no deposits in Alaska that have produced thorium or the rare earths, and the possibility of such production is limited. In Alaska, thorium-bearing minerals have been recognized at 47 localities which are described in U。 S. Geological Survey Circular 202 (Bates and Wedow, 1953). Circular 202 also indicates those deposits which might, with a change in economic conditions, come into production or byproduct production of thorium-bearing minerals.

Monazite has been the principal ore of thorium and the rare earths produced from foreign deposits. The main world sources of monazite in the last forty years have been the beach deposits of India and Brazil (Carlson, Keiser, and Sargent, 1953, p. 9)。 Other areas which haveproduced,monazite from beach placers are Ceylon, Malaya, parts of Africa and western Australia (Petar, 1935, p. 16, 17). A small quantity of monazite has been produced from pegmatites in southern Norway as a byproduct of feldspar mining (Petar, 1935, p. 18). Lode deposits of monazite have been reported in the Union of South Africa and in Uganda (Carlson, Keiser and Sargent, 1953, p。9)。 
Explanation of selected annotated bibliography. index and index map

The following selected annotared bibliography includes books, articles and other publications generally available in September 1954, on thorium and rare-earth deposits in this country and Alaska. Mary general papers are also included. Entries are arranged alphabetically by author. The index to the bibliography cross-references the alphabetical listing by locality and subject. An effort has been made to include in the bibliography references to those deposits which produce or may produce thorium and/or the rare earths and to exclude those references dealing with minor occurrences of primarily mineralogical interest; however, the extensive" Bibliography and index of literature on uranium and thorium and radioactive occurrences in the United States" by Margaret Cooper (1953, 1954) does include references to minor occurrences of thorium-bearing minerals and many rare earth-bearing minerals.

The index maps (figs. 1 and 2) show those deposits in the United States and Alaska for which information was available in September 1954 and which may produce or have produced thorium and/or rare earth-bearing minerals either as principal products or byproducts. The type of deposit is indicated by symbol, and the presence of important amounts of thorium or the rare earths is indicated by letters The $^{\circ}$ name of the mining district or area of the deposits is included on the map. 


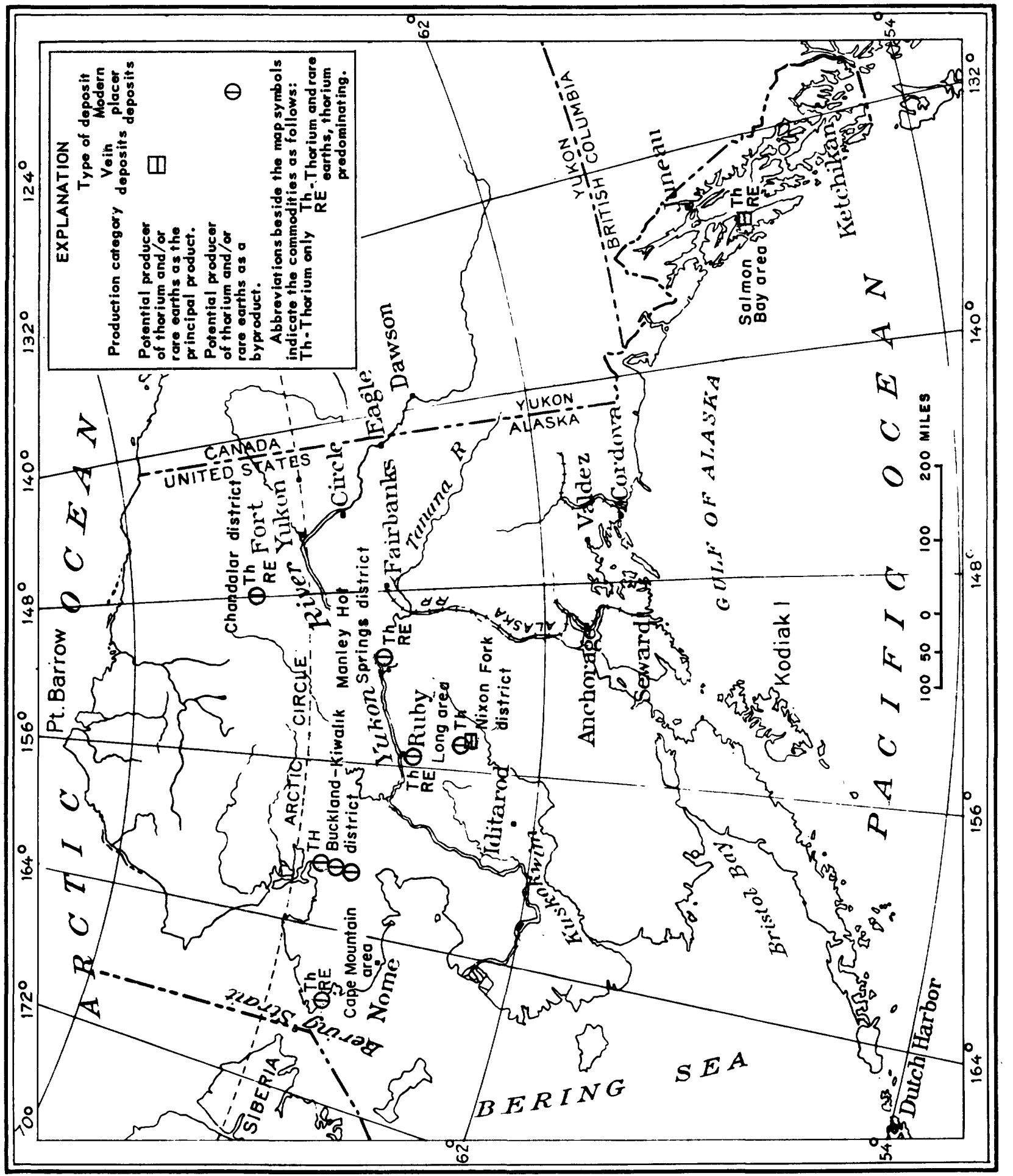

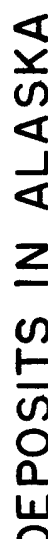

I

똥

岁

.

ن

똥

ㄸ 흥

0 웅

$\sum>$

$\sum \frac{0}{0}$

뚱 홍

L

4

$\frac{a}{2}$

$x$

늘

i

옹 


\section{SELECTED ANNOTATED BIBLIOGRAPHY}

Abbott, $A_{0} T_{0}, 1954$, Monazite deposits in calcareous rocks, northern Lemhi County, Idaho: Idaho Bur。 Mines and Geology, Pamphlet 99,24 p。

Between North Fork and Shoup, Idaho, immediately north of the Salmon River, several thin beds of marble are interbedded with the paragneisses and schists that belong to the vast assemblage of metamorphic rocks derived from the Precambrian Belt series. Crystalline aggregates and disseminated crystals of the radioactive phosphate mineral monazite, occur sporadically within the beds of marble. Other minerals commonly associated with the monazite are actinolite, barite, siderite, aparite, ilmenite and magnetite. A genetic interpretation involves the migration of rare earth elements during metamorphism of sandy, argillaceous sediments of the Belt series to a more compatible environment 0 :: phosphatic limestone in which porphyroblasts of monazite were formed. Although relatively little is known at the present time concerning the value of these deposits, results of this investigation should encourage further exploration and development. (Author's abstract).

Argall, G. O.. Jr. . 1954, New dredging techniques recover Idaho monazite: Min。 World, v。 16, no. 2. p. $26-30$.

Dredging operations for monazite, begun in Idaho in 1950 and now carried on by BaumhoffMarsha11, Inc., Idaho-Canadian Dredging Company and the Warren Dredging Corporation, are de-

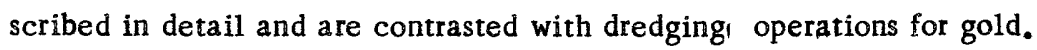

The main recovery problem in dredging for monazite is caused by the irregularity and wide variation in heavy mineral content of the sand which do not allow the jigs to be set for a uniform feed。 Test drilling and sampling are used to block out areas for dredging, and churn drilling is operated directly ahead of the dredges.

This newly created mining industry has made the United States independent of imports of monazite.

Atkinson, A. S. , 1910, Mining for the rare minerals: Min, Sci., vo61, Jan, 27, 1910, p. 76-77。 Gadolinite from Llano County, Tex. . and from Henderson County,' N. C. , has been mined and used for gas light mantles. Gadolinite used in the Nerist lamp contains 40 to 45 percent yttria. 
Bates, $R_{0} G_{0}$ and $W$ zoow, Helmutho $r_{0}, 1953$. Preliminary summary review of thorium-bearing mineral occurrences in Alaska: U. S. Eeol, Survey Circ, 202, 13 p.

Of the forty-seven known thorium -bearing mineral localities in Alaska, only a very few may have commercial possibilities. These are the Salmon Bay area. Prince of Wales Island; the Tofty tin beli in the Manley Hot Springs district, central Alaska; the Long area in the Ruby-Poorman district, central Alaska; the Nixon Fork area, central Alaska; the Buckland-Kiwalik district, eastern Seward Peninsula; the Cape Mountain area, western Seward Penfnsula; and the Chandalar district, northeastern Alaska.

The thorium-bearing minerals at each lodality are listed in the text and indicated on a map. Published and unpublished literature is cited.

Burbank, W. $S_{0}$, and Pierson, $C_{0} T_{0}, 1953$, Preliminary results of radiometric reconnaissance of parts of the northwestern San Juan Mountains, Colorado: $U_{0} S_{0}$ Geol。 Survey Circ. 236, 11 p.

Radiometric reconnaissance survey of parts of the San Juan Mountains has resulted in the discovery of thorium-bearing quartz-carbonate-sulfide vein deposits in the Cebolla (Powderhorn) district, Gunnison County, Colo.. and uranium-bearing ores in several districts in Ouray and San Juan Counties. The pre-Jurassic thorium-bearing veins of the Cebolla district cut Precambrian schists and greenstone. The veins, which are not of economic significance at this time, have been subjected to several cycles of erosion and leaching. Locally they are jasperized. Leaching of uranium disintegration prod:acts in the Cebolla district is in progress now.

Cannon, $H_{0} B_{0}, 1950$, Economic minerals in the beach sands of the southeastern United States, in Symposium on mineral resources of the southeastern United States: Univ $v_{0}$ of Tenn, 1949 Proc $_{0}, K_{n o x v i l l e}$ Tenn $_{0}$. p. 202-210。

According to present practice, an economically workable beach sand deposit in the southeastern with United States must have a reserve of a million tons $\partial f$ minerals heavier than 3,0 specific gravity making up four or five percent of the sand. Smaller deposits must be of higher grade. The main ore mineral of beach sand deposits is ilmenite, and a deposit to be workable must contain two or three hundred 
thousand tons of this mineral. Ilmenire is used chiefly in the production of white pigment. Changes in the several variable characteristics of the mineral often require costly changes in the processing plant. Therefore, ilmen ite is usually purchased by the titanium pigment industry in large lors of known characteristics rather than in small odd lots.

Only two beach sand deposits are being worked in the southeastern United States, one nine miles east of Jacksonville, Fla . and the other at Trail Ridge, 45 miles southwest of Jacksonville. Other deposits worked in the past in Florida were at Pablo Beach, Vero Beach, two miles inland from Vero Beach, and the west shore of Indian Rivter lagoon.

It is probable that there are still undiscovered large high-grade economic ore bodies in the southeastern United States. Because of high water table. thick vegetation and low-grade sand cover: discovery of such deposits requires systematic exploration programs using mechanical drills. The best deposits now known are in the old raised beaches, with only small deposits having been found in the modern beaches.

The sources of beach sand deposits of the southeastern states are the crystalline rocks of the southeastern Piedmont province. The heavy minerals have been concentrated, after erosion from the original rock and transportation by streams and rivers to the sea, into "stormline" deposits of heavy minerals on the active beaches or in lagoons and dunes.

The heavy minerals of Florida are divided into two assemblages, the Gulf assemblage and the Atlantic Coast assemblage. Staurolite and kyanite are the main constituents of the Gulf assemblage. The Gulf assemblage also includes zircon with few inclusions, ilmenite containing 64 to 65 percent titanium oxide, and no hornblende or epidote. In the Atlantic Coast assemblage there is little staurolite and kyanite, hornblende and epidote are the main constituents, the zircon contains many inclusions, and the ilmenite contains only 52 to 56 percent titanium oxide. Other heavy minerals likely to occur in both assemblages are leucoxene, rutile, monazite, rourmaline, pyroxene, garnet, andalusite, spinel, corundum, collophane, and limonite. 
Carlson, E. Jo, Kaufman, $A_{0} J_{0}, J_{r_{0}}$ Keiser, $H_{0} D_{0}$ and Needleman, Stanley, 1953, Minor metals: Minerals Yearbook, 1951, preprint。1, 11-13。

The activities of the $U_{0} S_{0}$ Bureau of Mines in searching for monazite in Idaho, Montana and the Carolinas are mentioned, Climax Molybdenum $\mathrm{Co}_{0}$, Leadville, Colo, is listed as a producer of monazite. Purchasers, uses and prices of monazite are lisped along with a brief world review.

Carlson, E。 J., Keiser, $H_{0} D_{\circ}$, and Sargent, J. D.. 1953, Minor metals: Minerals Yearbook, 1952, preprint, p. 7-9.

The activities and success of the $U_{0} \mathrm{~S}$. Bureau of Mines in searching for monazite in the Carolinas , Georgia, Florida,Idaho, Montana and Wyoming are mentioned, The United States may soon become independent of foreign sources of rare earths because of the recent discoveries of monazite and bastnaesite deposits in this country. The principal producers of monazite in this country in 1952 are three Idaho companies, --3aumhoff Marshall, Inc.. the Warren Dredging Corp., and the IdahoCanadian Dredging Co。 Monazite is also prociuced by the Humphreys Gold Corp. of Jacksonville, Fla., and bastnaesite by the Molybdenum Corp. of America at Mountain Pass, Calif. Processors of monazite ores are Lindsay Chemical $\mathrm{Co}_{0}$. which also processes bastnaesite concentrates; Rare Earths, : Inc., and Maywood Chemical Works.

The price of monazite in 1952 is quoted as $16-1 / 2$ cents per pound for 55 percent total rareearth oxides plus thoria, $f_{\circ} o_{\circ} b_{\circ}$ domestic mill; $18-3 / 4$ cents per pound for 64 percent; and 19 cents per pound for 65 percent. The price of mischmetal is $\$ 4.50$ and ferro-cerium $\$ 8.00$ per pound. Cerium metal of high purity is $\$ 18,00$ per pound. Rare earth chiorides are quoted at 45 to 50 cents per pound.

A brief world review states that lode deposits of monazite have been found in the Union of South Africa and Uganda. Monazite sand discoveries are reported from Madagascar, Brazil, and Argentina。 
Christman, $R_{0} A_{0}$ 。 Heyman, $A_{0} M_{0}$, Dellwig, $L_{0} F_{0}$, and Gort, $G_{0} B_{0}, 1953$, Thorium investigations, 1950-1952, Wet Mountains, Colorado: J。 S。Geol。Survey Circ。290, 40 p.

In the Wet Mountains, Colo. thorium-bearing minerals, principally thorite, occur in an area 20 miles long by 10 miles wide. The minerals occur in barite-sulfide veins in northwest-trending shear zones that cut a Precambrian igneous complex. The largest ore body is 300 feet long, 26 feet wide, and 400 feet deep. Some of the veins contain up to 4.5 percent equivalent thorium oxide。 Descriptions of the rock units and the deposits studied, geologic maps, logs of the eleven diamonddrill holes, and analyses of samples make up a large part of the text.

Congressional Documents, 1952, 82d Cong. . 2d sess. . H. Doc。527, v。 4, p。22, 23, 112-114.

The current need to increase domestic supplies of thorium and the rare earths has led to the discovery of deposits of monazite in Idaho and bastnaesite in New Mexico and California. New techniques for separating the rare earths will make it possible to develop new individual uses for these elements which are now often used in the mixture known as mischmetal.

Embargoes on the exportation of monazite from Brazil and India have raised the price of domestic monazite. The derelopment of, new uses for the rare earths has . been discouraged because the supply has been considered limited and the price, even of foreign ore,

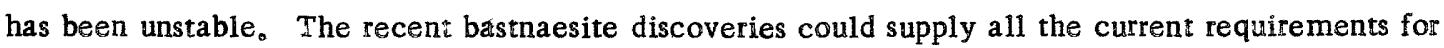
rare earths for many years and monazite mining could be abandoned if bastnaesite had a higher thorium content. Hence the thorium content of monazite continues to make it a mineral essential to our nation, and it is estimated that the probable production of monazite from Idaho will be from 3,000 to 5,000 tons a year for the years 1952 to 1955 .

Experiments with pure thorium are being carried on and indicate that the properties of the metal are such that there will be a continuing demand for thorium, even outside the field of atomic energy. 
1953, 83d Cong。

The United States is now becoming self-sufficient in rare-earth metals, largely through the intense search made for rare earth-bearing minerals since 1950. Promising deposits and adequate reserves of monazite have been found in South Carolina and in Idaho, and a large deposit of bastnaesite has been found at Mountain Pass, Calif。 Foreign sources have been cut off entirely since January 1951 . although there is a possibility that these sources might be reopened to the United States. Shipments of monazite have been contracted for from Africa for a 3-year period.

Substitutes are available for the rare earths in certain of their uses, such as in carbon arc electrodes and in flints for lighters.

Recommendations made to assure adequate supplies of rare earths are:

1) A stock pile sufficient for a five-year emergency.

2) Continued exploration for new placer deposits of monazite and byproduct minerals。

3) Development of markets for the byproduct minerals of monazite placer mining.

4) Continued studies to improve recovery of monazite and heavy minerals from placers and to improve extraction of rare earths from the ore.

5) Extensive study of the treatment of bastnaesite and its separation from gangue minerals.

6) Studies of the separation of individual rare-earth elements from their ores.

7) Research in metallurgy on the value and uses of the individual rare-earth metals.

Cooley, C. M. . 1953, Storke leve1 - Key to $\$ 25$ million Climax project: Min. Eng., v. 5, no, 1, p. 36-41. The flow sheet on $p_{0} 41$ shows clean monazite as a final product. 
Cooper, Margaret, 1953 and 1954. Bipliography and index of literature on uranium and thorium and radioactive occurrences in the United States: Geol. Soc. America Bull ${ }_{\infty}$, vo64, po 197-234, 1103-1172; v. 65, p. $467-590$.

This extensive bibliography will cover uranium thorium, and radioactive occurrences throughout the United States, although to September 1954 only the sections for Arizona, Nevada and New Mexico (pt. 1); California, Idaho, Montana, Oregon, Washington and Wyoming (pt。2); and Colorado and Utah (pt. 3) have been published. The bibliography contains a listing of articles by author, a gazetteer by states, a geographical index and a subject index. Geologic and mining literature has been reviewed through 1949 and a few standard publications through early 1952.

Day, D. T., and Richards, $R_{0} H_{0}, 1906$, Useful minerals in the black sands of the Pacific slope: Min。 Res. U。 S。 1905; p。1175-1258.

Heavy mineral analyses of various black sands obtained from placer mines throughout the western states are presented in tabular form by locality. Descriptions of the methods by which the sands were concentrated, methods of testing and examining the sands, results of concentration, and a bibliography are included.

Frondel, J, W., and Fleischer, Michael, 1952, A glossary of uranium- and thorium -bearing minerals: U. S. Geol。 Survey Circ。194, 25 p。 _'

This glossary contains a compilation of 1) minerals containing uranium and thorium as major constituents, 2) minerals containing uranium and thorium as minor constituents, 3) minerals that might show uranium or thorium content, and 4) minerals that of ten contain uranium, tharium, or the rare earths as impurities: or intergrowths. Formulas but not properties are given for most of the minerals and their relations to other minerals are indicated. The uranium and thorium content of each mineral is listed by percent.

_/ Now superseded by U. S. Geol. Survey Bull. 1009-F, 1955. The bulletin contains many additions, revisions, and corrections, and brings the glossary up to date as of July 1954. Minerals that contain uranium or thorium as major or minor constituents are listed, and their formulas given. Synonyms and discredited names are included. 
Gillson, J. L., 1949, Titanium: Chap。 49 in Industrial minerals and rocks, 2d ed, Am. Inst. Min。 Enge, New York, p. 1042-1073.

The geologic history common to most commercial beach sand deposits includes a source area of crystalline rocks, a period of deep soil formation and the decomposition of magnetite, a period of uplift and rapid erbsion of the soil tone, heavy mineral deposition in coastal plain sediments. subsidence and straightening of the coast, and, finally, elevation and erosion of the coast.

Glass, J. J., and Smalley, R。 G。 1945, Bastnäsite: Am. Mineralogi̊st, v。 30, nos, 9 and 10, p。601-615. Bastnaesite, a fluocarbonate of cerium metals, occurs in the fluorspar deposits of the Gallinas Mountains, N. Mex.. where the two minerals are associated with barite, barytocelestite, calcite. goethite, hematite, orthoclase, pyrite, quartz, and limonitic material along fissures and faults near the contacts of intrusive porphyritic quartz-monzonites, rhyolites and syenites with Permian sediments which overlie Precambrian granites. The physica1, optical and chemical properties of bastnaesite specimens from this locality are described and compared with the properties of bastnaesite from five other localities. This comparison suggests that bastnaesite has a constant chemical composition. The comparison also indicates that most of the know occurrences of bastnaesite are in contact with metamorphic rocks。 A bibliography is included。

Hess, F. L. . 1908, Minerals of the rare-earth metals at Baringer Hill, Llano County, Texas: J. S。 Geol. Survey Bull 340, P. 286-294.

A few hundred pounds per year of rare earths, mainly yttrium, and zirconium have been produced from this area for use in the Nernst lamp. The principal rare-earth minerals of the deposit are gadolinite, allanite, cyrtolite, fergusonite and polycrase containing the elements yttrium, beryllium, cerium, praseodymium, neodymium, lanthanum, zirconium, niobium, and uranium. The minerals occur in a pegmatite which has been intruded into Precambrian granite.

Houk, L. G。, 1943, Monazite sand: U。 S。 Bur. Mines, Inf. Circ. 7233, 19 p. This circular includes analyses of foreign and domestic monazite sands, world production figures for the period 1893-1938, a review of tariff history, domestic production and imports figures. a description of the uses of monazite, and a list of importers and consumers of monazite sands. 


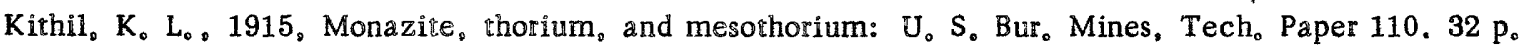
This paper presents the history of world production of monazite, including the German thorium conventions; descriptions of domestic and Brazilian deposits; methods of mining and milling monazite; a description of the separation, determination and uses of mesothorium; and a selected bibliography on monazite, thorium and mesothorium.

Kremers, H. E., 1949, The rare earth industry: Jour, of the Electronchem. Soc., v。 96, no. 3, p. 152-157. The industriat treatment of monazite sand for the extraction of cerftum and other rare earths arid . the uses of the rare earths are described briefly. A bibliography is included.

Levy, S. I., 1915, The rare earths, their occurrence, chemistry and technology: Edward Arnold, London $345 \mathrm{p}$.

This well documented older book includes descriptions of the minerals, the mode of occurrence, chemistry, and technology of the rare earths. The incandescent mantle industry, the chemical treatment of monazite, artificial silk and its application to the mantle industry' and other early technological and industrial uses of the rare earths are described.

Lindgren. Waldemar, 1898, The mining districts of the Idaho Basin and the Boise Ridge, Idaho: $U_{0} S_{0}$ Geol. Survey 18th Ann. Repr。 pro 3, p。677-679。

The heavy minerals derived from the granites of the Idaho Basin are found in the sand of the gravels and lake beds of the region. Throughout the Basin, monazite forms a large percentage of the heavy minerals. Samples of monazite from three miles east of Idaho City and from Wolf Creek near Placerville are described. This is the first report of monazite placers in Idaho.

Mertie, J. $\mathrm{B}_{\circ}, \mathrm{J}_{\mathrm{r}}$, 1949, Monazite: Chap。 30 in Industrial minerals and rocks, 2d ed. Am. Inst, Min。 Eng., New York。 p。629-636. Monazite, the rare earths and thorium are described as to characteristics, occurrence, production。 economic control and uses. A bibliography is included. 
1953, Monazite deposits of the southeastern Atlantic states: U. S. Geol。 Survey Circ。237.

$31 \mathrm{p}$

Monazite, the principal ore mineral of thorium and the rare earths, was mined from fluviatile placers in the Piedmont province of the Carolinas from 1887 to 1917 with some interruptions. From 1917 to 1946 monazire was imported from India and Brazil, and since 1946 the embargoes on exportation of foreign monazite have made it a scarce commodity in this country. Monazite is now being produced in Idaho as well as in Florida, where it is a byproduct of the ilmenite mining near Jacksonville.

New deposits of monazite have been discovered in the southeastern Piedmont, and the placers which were formerly mined have been re-evaluated. The latter were not exhausted by mining and many of the deposits have been rejuvenated. Mining in the area is complicated by the predominance of farming and by the uncertainty of the future value of monazite. These deposits are, however. a reserve which could be invaluable in a time of emergency.

Monazite in the southeastern Piedmont province of complex metamorphic and igneous rocks occurs in two belts, a western belt that is traced from east-central Virginia southwestward into Alabama and an eastern belt from near Fredericksburg. Virginia, south-southwestward into North Carolina. These monazite belts may have been the sites of Precambrian valleys where detrital monazite was concentrated and later reconstituted into gneisses or remelted into intrusives.

The western monazite belt includes the area of placers formerly mined in the Carolinas. Results of sampling of the early headwater placers show up to 8.4 pounds of monazite per cubic yard and a mean content of 5.7 percent thorium oxide. These placers do not contain sufficient yardage to be mined by large-scale methods.

The principal source rocks in the monazite belts are certain granitic intrusives, granitized and pegmatized country rock, and certain granitic phases of the Carolina gneiss. There is a mean tenor of 0.006 percent monazite in the bedrock. 
Moxham $R_{0} M_{0}$ 1954, Reconnai issance for adioactive deposits in the Manley Hot Springs-Rampart district。 east-central Alaska, 1948: U. $S_{0}$ Geol。 Survey Circ。317, 6 p。

The radioactive minerals eschynite, ellsworthite, columbite, monazite and zircon have been found in the gold-tin placer deposits of the Tofty area, east-central Alaska The bedrock source of these minerals was not found although monazite is present in the granite country rock and geologic data suggest a common local bedrock source for both the cassirerite and the radioactive minerals of the Tofty tin placers.

Under present conditions the radioactive minerals of the Tofty placers are probably not sufficiently concentrated to be recovered as a byproduct of the gold and tin mining.

Murata, $K_{0} J_{0}, R_{0 s} e_{0} H_{0} J_{0}, J_{0}$, and Carron $M_{0} M_{0} K_{0}, 1953_{0}$ Systematic variation of rare earths in monazite: Geochimica et Cosmochimica Acta。 v。 4, po 292-300,

Ten monazite samples from scatiered localities have been analyzed for the individual rare-earth elements by a combined chemical and emission spectrographic method. Rules are given for the variation in the proportions of the rare-earth elements. Variation trends are explained by fractional precipitation and deviacions from the trends by abnormally high or low temperatures.

Nitze, Ho $, C_{0}, 1895 a$, Monazite and monazite deposits in North Carolina: North Carolina Geol。 Survey Bull.9.47 p。

Monazite is briefly described and its history, nomenclature and crystallography are reviewed。 Chemical analyses of monazite from various localities are given. The geologic and geographic occurrence of monazite is described. Also covered are the uses, methods of extraction and concentration, and the production and value of monazite. A bibliography is included。 
1895b, Monazire: $U_{0} S_{0}$ Geol。 Survey 16th Ann。 Repto pt。4,

The mineralogical and chemical nature of monazite is described and a brief sketch is given on the history and nomenclature of the mineral. The methods of anaiysis are presented. Geologic and geographic occurrence of monazite is presented in tabular form. The uses, methods of extractlon and tancentration, prodmetion and value are described. A good early bibliography is inciuded.

Olson, Jo $C_{0}$. Shawe, $D_{0} R_{0}$, Pray $_{0} L_{0} C_{0}$, and Sharp, $W_{0} N_{0}$ 1954, Rare-earth mineral deposits of the Mountain Pass district, San Bernardino County, California: U。 S. Geol. Survey Prof. Paper 261.75 p。 Bastnaesite, a rare-earth fluocarbonate, was discovered in the Mountain Pass district in April 1949. Geologic mapping has shown that rare-earth mineral deposits occur in a belt about 6 males long and 1 1/2 mile wide. One deposit, the Sulphide Queen carbonate body, is the greatest concentration of rare-earth minerals now known in the world. The report describes the district, the history of the discovery, the rare-earth and thorium deposits, and the alkalic igneous rocks with which the deposits are associated. Geologic maps of the district and of selected mineral deposits accompany the report.

The radioaccive minerals occur in mineralized shear zones characterized by abundant hematite and goethite, and in the carbonate rocks. The radioactivity is due almost entirely to thorium and its decay products。 The uranium content of vein samples, determined chemically, is low, the highest value being 0.020 percent uranium. Thorium oxide, however, is more than 2 percent of some selected samples. the strongest radioactivity is attributable chiefly to thorite and thorogummite and to a lesser extent to monazite which occurs in and near the Sulphide Queen carbonate body. 
Parks, R. D。, 1949, Source materials for nuclear power, in Goodman, Clark, ed。. The science and engineering of nuclear power, $v_{0} 2, p_{0}$ 1-18: United States of America, Addison-Wesley Press, Inc.

Thorium is not a particularly scarce element in the earth's crust; it is found in about the same quantity as tin, cobalt, zinc or lead, Economically workable concentrations of thorium are, or have been, less common than those of tin, cobalt, zinc or lead,

Monazite, for all practical purposes, has been the only commercial source of thorium, and it is generally considered to have been derived from pegmatite sources. Economic deposits have been concentrated into placers by the weathering of such pegmatites.

The monazite mining capacity of India is about 7000 tons per year, which could be increased by shifting operations from low-monazite high-ilmenite sands to sands richer in monazite. The monazite mining capacity of Brazil is about 1500 tons per year, which could be increased by adding equipment or going on two shifts. Australia's capacity is about 100 tons per year.

The monazite reserves of India were estimated 25 years ago to be over 2,000,000 tons on a basis of beds 2 feet thíck containing 10 percent monazite. They have not been seriously depleted. Brazilian deposits are thought to be of similar magnitude. Ceylon deposits are stated to be very rich but not extensive.

Petar, A. V.. 1935, The rare earths: U。 S. Bur. Mines, Inf. Circ。6847, 46 p。

This is a general paper, with a good bibliography, on the rare earblus. It includes a description and list of properties of the-individual elements by family and reviews the history of their discovery. Tables are presented of the abundances of rare earths in the earth and of rare earth-bearing minerals and their occurrence. The chemical separation of these elements is described The rare-earth industry, both foreign and domestic, is described. Tables of imports and exports, a discussion of tariff regulations, markets and prices, and a list of producers, dealers and possible buyers of rare earths are included. 
Pratt, J. $H_{0}, 1916$, Zircon, monazite and other minerals used in the production of chemical compounds employed in the manufacture of lighting apparatus: North Carolina Geol。 and Econ。 Survey Bull,25. p. 19-69.

This is an excellent report on the minerals and uses of rare earths, especially yttrium, thorium, cerium and lanthanum. The occurrence of monazite is covered thoroughly by a table of foreign and domestic localities which lists the country rock and minerals associated with each locality. The Carolina and Idaho areas are described in more detail. Production in North Carolina from 1893 to 1915 is reviewed. A full description is given of the mining and cleaning of the Carolina monazite sands, including an attempt at mining saprolite. A description of the Brazilian deposits, the history of foreign trade in monazite, and import and export data on monazite and thoria are included.

1917. Monazite in the United States: Min. Foote-notes, v. 1, no. 10, p. 3-15.

A table of occurrences of monazite lists for each locality the country rock and associated minerals. The Carolina and Idaho deposits and the types of rock in which they occur are discussed. A description of monazite and a brief discussion of its uses are included.

Pratt, J. $H_{0}$ and Sterrett, D. B., 1910, Monazite and monazite-mining in the Carolinas: Trans. Am. Inst。 Min. Eng., vo 40, po 313-340。

Monazite and its occurrences in the United States are described along with the geology and deposits of the Carolina monazite region。 A description of the separation and uses monazite is included。

Roots, E。 F., 1946, Cerium and thorium: Western Miner, v. 19, no. 8, p. 50-56.

In this brief article in which minerals carrying cerium and thorium (particularly monazite, thorite, auerlite, thorianite, and xenotime) are described, and placer and lode deposits of ceriumand thorium-bearing minerals, both foreign and domestic, are reviewed. This article also covers the production $i$ and consumption of cerium and thorium; mining and milling; marketing, shipping and duties; extraction of cerium and thorium compounds from monazites; byproducts and utilization; and grades, prices, and buyers of cerium and thorium products and ores. 
Santmyers, $R_{0} M_{0}, 1930$, Monazite, thorium and cerium: U. So Bur. Mines, Inf。Circ。6321, 43 p。 Thorium- and cerium-bearing minerals and ores, especially monazite, are reviewed, and tests for their identification, history of their discovery, and brief descriptions of their mode of occurrence and geographical distuiburion are given。 Other topics especially well covered are domestiz and world production, imports, exports, trade, and the tariff history of monazite, thorium and cerium。 The incandescent gas mantle industry is described and other uses of thorium and cerium are discussed。 Mesothorium is described and imports listed。A good bibliography is included。

On p. 11 it is mentioned that at Mineral City, Fla, 4 miles south of Jacksonville Beach, monazite, along with zircon and rutile, was recovered as a byproduct of ilmenire mining. In 1925 there was a reported production of 2.000 pounds of monazite from this deposit.

Schaller, $W_{0} T_{0}, 1922$. Thorium, zirconium, and rare-earth minerals: Min。 Res, U. S. . 1919: pt, 2. p. 1-32.

This report includes a review of the thorium and rare-earth industry with production and import data, both foreign and domestic; foreign and domestic producing localities; uses; and a review of the sources of ore. Monazite, thorive, auerlite, and thorianite are described and analyses of foreign and domestic monazites with percentage of thoria are given. A good selected general bibliography covering foreign and domestic occurrences is included.

Schrader, F。C.。1910, An occurrence of monazite innorthern Idaho: U。 S. Geol. Survey Bull. 430, p. $184-191$ 。

Occurrences of monazice are reported in Idaho on Mussel Shell Creek, Nez Perca (now Clearwater) County, near Dent, and in the Pierce district, Idaho, The Mussel Shell Creek deposit is described and analyses of the monazite from this locality are given.

The origin and distribution of monazite in Idaho is discassed and related to the Idaho batholith. A bibliography is included. 
Sharp, $W_{0} N_{0}$, and Pray, $L_{0} C_{0}, 1952$, Geologic map of bastnaesite deposits of the Birthday claims, San Bernardino County, California: U. S. Geol. Survey Min. Inv. Field Studies Map MF 4.

The Precambrian metamorphic complex, country rock in the Birthday claims area is intruded at the Birthday claims by a body of shonkinite which contains most of the bastnaesite veins in the area。 The shonkinite and enclosing gneiss are cut in turn by fine-grained granite bodies and other intrusives.

The barite-rich bastnaesite-bearing carbonate veins follow a west- to northwest-trending fracture system which cuts the Precambrian metamorphic complex as well as the intrusive sequence. The veins have been divided into six types on the basis of mineralogy.

The main minerals of the ore veins are bastnaesite, calcite and other carbonates, barite, quartz and fluorite. The paragenesis of the minerals, at least locally, is bastnaesite, barite and the carbonates. Quartz and fluorite may have been deposited later.

Thorium is the main radioactive element in the veins and in the shonkinite, which is more radioactive than the country rock. The largest concentrations of thorium, and uranium, are in limonitic alteration products found in the weathered veins. Small amounts of these elements occur in the bastnaesite.

Sloan, Earle, 1908, Catalogue of the mineral localities of South Carolina: South Carolina Geol. Survey ser。 4, Bull. 2, p. 129-142.

The geographic limits of monazite zones in South Carolina are described and detailed locations of monazite gravels in the state are given.

Soulé, J。 $H_{0}$, 1946, Exploration of Gallinas fluorspar deposits, Lincoln County, New Mexico: U. S. Bur。 Mines, Rept. Inv. 3854.25 p。

Bastnaesite was discovered in the Gallinas deposits during the Bureau of Mines drilling program in 1943-44. Methods for separating the bastnaesite are discussed. Analyses of bastnaesite are included。 
Staley, W. Wo, 1948, Distribution of heavy alluvial minerals in Idaho: Idaho Bur. Mines and Geology.

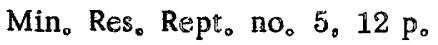

The mineralogical and chemical compositon of black sands, their commercial use, and the distribution of such sands in Idaho are described. Assay results on Idaho heavy sands are given by localities along with chemical and spectrographic analyses. The estimated tonnages of monazite. zircon, and ilmenite available in Idaho are listed. The amount of monazite listed as available is 181,500 tons。

Staley, W. W。 and Browning, Jo $S_{0}, 1949$, Preliminary investigation of concentrating certain minerals in Idaho placer sand: Idaho Bur:, Mines and Geology Pamph。87, 23 p.

Increasing interest in certain heavy minerals accumulated in placer deposits brought about this study on the methods of concentrating monazite, zircon, ilmenite and magnetite in material obtained primarily from dredging operations in the Boise Basin, Idaho. The experimenal method found successful in separating these minerals is a combination of screening, flotation, and magnetc separation.

Sterrett, D。 B. 1907, Monaz ite and zircon: Min, Res, U。 S, 1906: p. 1195-1209.

The monazite industry as a whole is reviewed and the geology of monazite deposits and the mining and cleaning of the monazite sand in North Carolina, South Carolina, and Georgia are described. The deposits in Idaho and in foreign countries are reviewed. Figures are given on price. production, imports and exports of monazite.

1911. Monazite and zïrcon: Min。 Res。U.S., 1909; pt.2, p. 897-905。

The monazite deposits near Centerville, Idaho, and the operation of the Centerville Mining and Milling Company along Grimes and Quartz Creeks, Idaho, are described along with the methods of mining and concentrating used and the estimates of the monazite and thoria content of the deposits. 
Trites, $A_{0} F_{0}, J_{0}$, and Tooker, $E_{0}, W_{0}, 1953$, Uranium and thorium deposits in east-central Idaho and southwestern Montana: U。 S。 Geol。 Survey Bull. 988- $H_{\text {, }}$ p $184-208$ 。

Monazite occurs in Precambrian pegmatites of the Deer Creek district, Monto ( $p_{0}$ 184-191) at the Divide nos. 1 and 2 claims and a $\mathrm{E}$ the Gray Goose claims where allanite also occurs in the pegmatite. The Lookout no, 3 claim in the same district contains an hydrothermal carbonate vein。 a sample of which contained 0.24 percent thorium oxide and 2.71 percent rare earths, cutting Precambrian (?) gneissic hornblende diorite.

The eleven deposits examined in the Lemhi Pass district ( $p_{0}$ 191-208) are found to contain thorium. Thorite is the main thorium-bearing mineral and occurs in quartz-hetmatite veins which fill fractures in the Precambrian Belt series and which measure from less than 1 foot to 50 feet in width and from 10 to more than 700 feet in length. Other minerals in the veins are goethite, chalcedony, and barite. Samples from the veins contain as much as 6,6 percent calculated thorium oxide, and spectrographic

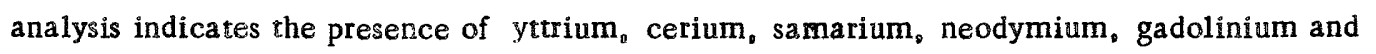
lanthanum.

Copper veins also occur as fracture fillings in the Belt series in the Lemhi Pass district. The radioactivity of these veins is similar to that of the quartz-hematite veins and is thought to be caused by thorium.

The claims and mines checked in the Lemhi Pass district are the Wonder Lode mine, the Buffalo nos, 1 and 2 claims, the Wonder Lode no, 18 claim, the Lucky Strike nos, 1 and 2 claims, the Trapper nos, 1 and 4 claims, the Radio claim, the Brown Bear claim, the Last Chance claim and the Shady Tree claim.

U. S. Atomic Energy Commission, 1954, Sixteenth semi-annual report of the Atomic Energy Commission: Washington, D. C. U. S. Govt。 Printing Office, p. 25。

The Atomic Energy Commission now has an homogeneous thorium reactor in the planning stage. This reactor will use thorium as a blanket from which uranium 233 will be produced. Construction of the reactor is planned to begin in fiscal year 1957 and to be completed in fiscal year 1959 , 
West, $W_{0} S_{0}$ and Matzko, $\mathbb{J}_{0} \mathbb{J}_{0}$ 1953, Buckland-Kiwalik district, 1947, Chap。 $\mathrm{D}$ in Gaulr $\mathrm{H}_{0} \mathrm{R}_{\mathrm{o}}$. and others, Reconnaissance for radioactive deposits in the northeastern part of the Seward Peninsula. Alaska, 1945-47 and 1951: U。 S Geol。 Survey Cirre, 250, po 21-27。

Uranothorianite and thorite are the most important of the radioactive minerals found widely distributed in the Buckland-Kiwalik district. These minerals occur mainly in well-defined placer zones within areas of granitic rock and are thought to be concentrated accessory minerals from the differentiate phases of certain of the granitic rocks, It is possible, however, because of the presence of metallic sulfides, that some of the uranium was introduced during a period of hydrothermal alteration of the granitic rocks. Concentrations of uranothorianite are found in the headwaters of the Peace River。 Quartz Creek, and Sweepstakes Creek on Granite Mountain; in the Hunter CreekConnolly Creek area; and on Clem Mountain. The Peace River placer locality may be a lead to a high=grade uranioum Iode.

White $M_{0} G_{0}$, and Stevens, Jo $M_{0}, 1953$, Reconnaissance for radioactive deposits in the Ruby-Poorman

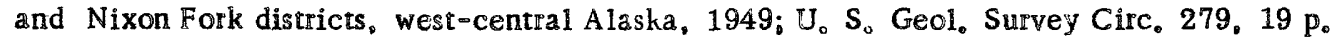

In the Long area of the Ruby-Poorman district are two small granite bodies with an average equivalent uranium content of 0.005 percent This radioactivity is due largely to uranothorite (?) disseminated throughour the granite. No high concentrations of the mineral were found.

In the Nixon Fork district uraniferous thorianite, allanite and other radioactive minerals'whose radioactivity is.principally due to thorium, were found in the placers of Hidder Creek, Ruby Creek and Eagle Creek. Bedrock occurrences are found at the whalen mine where the tare earth mineral parisite is found along with allanite, radioactive hematite andsphene, and zircon; in the monzonite of the Ruby Creek area which contains zircon and sphene; and the Nixon Fork mine.

Anonymous, 1949a, Monazite production: Min. Cong, Jour, $\mathrm{v}_{0} 35, \mathrm{no}_{0} 7, \mathrm{p} 71$.

Rare Earths Mineral $\mathrm{CO}_{\bullet}, \mathrm{McCall}_{\mathfrak{v}}$ Idaho, is extracting monazite from Idaho sands and is contracting to ship 16,000 tons of concentrated sand during the next 10 years. 
Anonymous, $1949 \mathrm{~b}$, Monazite reseatch: Min, Cong, Jour。, v。 35. no, 9, po 82 。

Universicy of Idaho School of Mines is conducting a research program on the rare earths recovered as byproducts in the milling of monazite sand。

Idaho placer gravels are being treated for monazite content at a plant at McCall. Idaho. anc

1950a Idaho - Operation of a bucket-line dredge on Big Creek: Eng。 and Min. Jour 。 v. 151.

no, 11, po 130 。

A bucket-lime dredge on Big Creek, Idaho, is producing monazite and gold and is handling 5,000 to 6,000 yards of gravel daily.

$1950 \mathrm{~b}$. Wyoming - Atomic energy representatives investigating the uranium deposits

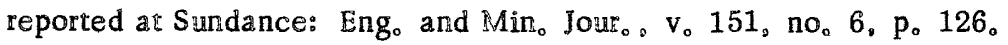

The uranium deposits at Sundance, Wyo, contain low grade uranium and rare-earth oxides。

1952a . Companies join with Heim to develop bastnasite: Eng. and Min. Jour ${ }_{\circ}$ พ. $153_{\diamond}$

no. 1. p. 108 。

The Gallinas district, Lincoln County, $N_{0} M_{\text {ex }}$. produces each month several carloads of

rare-earth ore which is shipped to Lindsay Light and Chemical Company.

1952b. Fred Baumhoff。 Centerville, Idaho: Engo and Min. Jour., v. 153, no, 2, p. 168-169.

Fred Baumhoff, operating near Cascade, Idaho, has shipped $1_{0} 000$ tons of monazite to Lindsay

Light and Chemical Company。

$1952 c_{\text {, Southern California }}{ }^{\circ}$ rare earth bonanza: Eng, and Mitn。 Jour ${ }_{\omega \infty} v_{0} 153$,

no. 1. po 100-102。

The Mountain Pass district's massive bastnaesite-barite veins are described and an estimate of their size and grade is given. The ore dressing problem is discussed. A history of the discovery and development of the district is presenced. 
Anonymous, 1954a, Atlantic beaches radioactive: $\mathrm{Min}_{\mathrm{o}}$ Cong。 Jour., $\mathrm{v}_{0} 40, \mathrm{no}, 1, \mathrm{p} .63$ 。

The $U_{0} S_{0}$ Geological Survey has released maps showing the location of radioactivity anomalies detected along parts of the Avlantic Ocean beach from Cape Henry, Va $a_{0}$, to Cape Fear $N_{0} \mathrm{~N}_{0} \mathrm{C}_{0}$ and from Savannah Beach, $\mathrm{Ga}_{\circ}$, to Miami Beach, Fla. These anomalies may or may not indicate the presence of uranium or thorium:

$1954 \mathrm{~b}$, Dredges work Idaho sand: Eng。 and Min。 Jour。, vo 155, no. 3, p. 190.

Dredges operazing in the Long Valley, Idaho, area are recovering monazite from gravels which contain about $151 / 2$ pounds per cubic yard of black sand which in turn contains about $71 / 2$ percent monazite. The black sand is separated at Boise in the Baumhoff-Marshall Inc, plant. Half of the monazite, which contains about 60 percent rare-earth metals, is purchased by Lindsay Light and Chemical Company and half by the Government for stockpiling.

Bear Valley, Idaho, is reported to be a new source of radioactive elements, including thorium and rare earths. Production in Bear Valley is scheduled to begin by September 1954.

1954c. Idaho dredge plans: Min。 Cong, Jour。 v, 40, no. 8, p. 127.

Preparations being made for large scale dredging in Bear Valley, Idaho, where a plant for processing the dredge products is to begin operations by September 1954. Monazite, thorium, tantalum, columbium, and uranium are to be recovered。

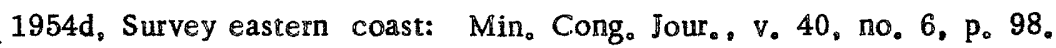

The U. S. Geological Survey has released maps showing the location of radioactivity anomalies detected along parts of the Atlantic Ocean beach between Cape Fear, N. C.. and Edisto Island, S。C $C_{0}$ and along the Gulf of Mexico between Sanibel and Caladesi Islands。 Fla. These anomalies … may or may not indicate the presence of uranium or thorium. 
Anonymous $1954 \mathrm{e}$. Three of central Idaho's placer deposits are currently producing radioactive minerals:

Eng, and $\mathrm{Min}_{0}$ Jour $_{0}, \mathrm{v}, 155$, no, 5, p。93.

The Bureau of Mines announces the production of rare-earth minerals, thorium, uranium, columbium, and tantalum, from the Big Creek, Boise Basin, and Ruby Meadows placers in Idaho。 The Bureau lists as potential producers Bear Valley. Secesh Meadows, Scott Valley, Horsethief Basin, Pearsol Creek and Corral Creek. 


\section{INDEX}

Alabama: Mertie。1953

\section{Alaska}

Buckland-Kilwalik districti: Bates and Wedow, 1953; West and Matzko, 1953

Cape Mountain area: Bates and Wedow, 1953

Chandalar district: Bates and Wedow。 1953

Long area: Bates and Wedow, 1953; White and Stevens, 1953

Manley Hot Springs district: Bates and Wedow, 1953; Moxham, 1954

Nixon Fork district: Bates and Wedow, 1953; White and Stevens, 1953

Ruby-Poorman district: Bates and Wedow, 1953; White and Stevens, 1953

Salmon Bay area: Bates and Wedow, 1953

Seward Peninsula: Bates and Wedow, 1953; West and Matzko, 1953

Tofty tin belt: Bates and Wedow, 1953; Moxham, 1954

Allanite; Hess, 1908; Trites and Tooker, 1953; White and Stevens, 1953

Analyses: Cannon, 1950; Christman and others, 1953; Day and Richards, 1906; Glass and Smalley, 1945;

Houk 1943; Mertie, 1953; Murata and others, 1953; Nitze, 1895a; Olson and others, 1954; Pratt, 19i6;

Schaller, 1922; Schrader, 1910: Soule, 1946; Staley。1948; Sterrett, 1911; Trites and Tooker, 1953.

Anomalies, radioactive: Anonymous, $1954 a^{2}$ 1954d

Argentina: Carlson, Keiser, and Sargent, 1953

Atlantic Ocean beaches: Cannon, 1950; Mertie, 1953; Anonymous, 1954a, 1954d

Auerlite: Roots, 1946: Schaller。 1922

Australia: Parks, 1949

Bastnaesite

Analyses: Glass and Smalley, 1945; Olson and others, 1954; Soule, 1946

Economics: Congressional Documents, 1952, 1953; Olson and others, 1954; Sharp and Pray, 1952

Geochemistry: Sharp and Pray。1952

Mineralogy: Glass and Smalley, 1945; OIson and others, 1954 
Occurrences: Carlson, Keiser and Sargent, 1953; Congressional Documents, 1952, 1953; Glass and Smalley. 1945; Olson and others. 1954; Sharp and Pray, 1952; Soule, 1946; Anonymous, $1952 \mathrm{a}, 1952 \mathrm{c}$

Processors: Carlson, Keiser and Sargent, 1953

Production: Congressional Documents, 1952,1953; Anonymous, 1952a

Treatment: Congressional Documents, 1953; Soule, 1946; Anonymous, 1952c

Beach sand deposits: Cannon, 1950; Gillson, 1949; Mertie. 1953; Parks, 1949; Santmyers, 1930;

Anonymous, 1954a, 1954d

Bibliography: Bates and Wedow, 1953; Cooper, 1953, 1954; Day and Richards, 1906; Glass and Smalley, 1945;

Kithil. 1915; Kremers, 1949; Mertie, 1949; Nitze, 1895a, 1895b; Petar, 1935; Santmyers, 1930;

Schaller, 1922; Schrader, 1910

Black sarteds:

Analyses: Day and Richards, 1906; Gillson, 1949; Staley. 1948; Staley and Browning. 1949

Brazil: Carison, Keiser and Sargent, 1953; Congressional Documents, 1952; Kithil, 1915; Parks, 1949;

Pratt, 1916

California: Cooper, 1953, 1954. Day and Richards, 1906

San Bernardino County

Birthday claims: Sharp and Pray, 1952

Mountain Pass district: Carlson, Keiser and Sargent, 1953: Congressional Documents, 1952, 1953;

Olson and others, 1954; Sharp and Pray, 1952; Anonymous, 1952c

Cerium: Carlson, Keiser and Sargent, 1953; Hess, 1908; Kremers, 1949; Petar, 1935; Pratr, 1916;

Roots, 1946; Santmyers, 1930

Ceylon: :Parks, 1949

Climax molybdenum deposit: Carlson, Kaufman, and others, 1953; Cooley, 1953

Colorado: Cooper. 1953, 1954

Custer County

Hardscrabble district (see Westcliffe district)

Westcliffe district: Christman, and others, 1953 
Fremont County

Hardscrabble district (see Westcliffe district)

Westcliffe district: Christman, and others, 1953

Gunnison County

Cebolla district (see Powderhorn district)

Powderhorn district: Burbank and Pierson, 1953

Lake County

Climax molybdenum deposit: Carlson,Kaufman, and others, 1953; Cooley, 1953

San Juan Mountains: Burbank and Pierson, 1953

Wet Mountains; Christman, and others, 1953

Cyrtolite: Hess, 1908

Dredging: Arga11, 1954; Anonymous, 1950a, 1954c

Fergusonite: Hess。 1908

Florida: Cannon, 1950; Carlson, Keiser, and Sargent, 1953; Anonymous, 1954a, 1954d

Duval County

Jacksonville placer: Cannon, 1950; Carlson, Keiser, and Sargent, 1953; Mertie, 1953

Mineral City: Santmyers, 1930

National Lead Company: Cannon, 1950; Mertie 1953

Pablo Beach: Cannon, 1950; Santmyers, 1930

F1uorspar: Glass and Smalley, 1945; Olson and others, 1954; Sharp and Pray, 1952; Soule, 1946

Foreign deposits: Carlson, Keiser, and Sargent, 1953; Congressional Documents, 1953; Kithil. 1915;

Roots, 1946; Schaller, 1922; Sterrett, 1907

Foreign trade: Congressional Documents, 1953; Kithil. 1915; Petar, 1935; Schaller, 1922

Gadolinite: Atkinson, 1910; Hess, 1908; Pratt, 1916 
Genera1: Carlson,Kaufman, and others, 1953; Carlson, Keiser, and Sargent, 1953; Congressional

Documents, 1952, 1953; Cooper。1953, 1954; Day and Richards, 1906; Gillson, 1949; Kithil 1915 ;

Levy, 1915; Mertie, 1949; ㅈiızze, 1895b; Petar, 1935; Pratt, 1916; Santmyers, 1930; Schaller, 1922

Geochemistry: Sharp and Pray, 1952

Georgia; Carlson, Keiser and Sargent, 1953; Mertie, 1953; Sterrett, 1907; Anonymous, 1954a

German thorium conventions: Kithil, 1915

Gulf of Mexico beaches: Cannon, 1950; Anonymous, 1954d

Heavy minerals: Cannon, 1950; Day and Richards, 1906; Gillson, 1949; Lindgren, 1898; Mertie, 1953;

Staley, 1948; Staley and Browning, 1949

Idaho: Arga11, 1954; Carlson, Kaufman and others, 1953; Carlson, Keiser and Sargent, 1953; Congressional Documents, 1952; 1953; Cooper, 1953, 1954; Day and Richards, 1906; Pratt, 1916, 1917;

Staley, 1948; Staley and Browning, 1949; Sterrett, 1907, 1911; Trites and Tooker, 1953;

Anonymous, $1949 \mathrm{a}, 1949 \mathrm{~b}$

Boise County

Centerville; Sterrett, 1911

Boise Basin: Staley and Browning, 1949; Anonymous, $1954 €$

Boise Ridge: Lindgren, 1898

Clearwater County

Dent: Schrader, 1910

Mussel Shell Creek; Schrader, 1910

Pierce district: Schrader, 1910

Idaho Basin: Lindgren, 1898

Idaho County

Ruby Meadows: Anonymous, 1954e

Secesh Meadows: Anonymous, 1954e

Lemhi County

Lemhi Pass district: Trites and Tooker, 1953

Mineral Hill district: Abbeit 1954 
Idaho--Continued :

Nez Perce County (see Clearwater County)

Valley County: Anonymous, 1952b

Bear Valley: Anonymous, 1954b,1954c, 1954e

Big Creek: Argall, 1954; Congressional Documents, 1953; Anonymous, 1950a, 1954e

Corral Creek; Anonymous, 1954e

Horse Thief Basin: Anonymous, $1954 \mathrm{e}$

Long Valley: Anonymous, 1954b

Pearsol Creek: Anonymous, 1954e

Scott Valley: Anonymous, 1954e

Idaho batholith: Lindgren, 1898; Schrader, 1910

Ilmenite: Cannon, 1950; Gillson, 1949; Mertie, 1953; Santmyers, 1930; Staley and Browning, 1949

Incandescent gas mantle industry: Atkinson, 1910; Levy, 1915;: Pratt, 1916; Santmyers, 1930

India: Congressional Documents, 1953; Parks, 1949

Lanthanum: Hess, 1908; Petar, 1935; Pratt, 1916

Madagascar: Carlson, Keiser, and Sargent, 1953

Mesothorium: Kithil, 1915; Santmyers, 1930

Mischmetal: See monazite, uses

Monazite: Congressional Documents, 1952, 1953; Cooper, 1953, 1954; Kithil, 1915; Kremers, 1949 ;

Mertie, 1949; Staley and Browning, 1949; Sterrett, 1907; Anonymous, 1949b

Analyses: Houk, 1943; Mertie, 1953; Murata and others, 1953; Nitze, 1895a; Schaller. 1922;

Sterrett, 1911

Byproducts: Congressional Documents, 1953; Roots, 1946

Chemistry: Murata and others, 1953; Niזze, 1895b

Economics: Congressional Documents, 1952, 1953; Mertie, 1949, 1953; Roots, 1946

Foreign trade: Congressional Documents, 1952, 1953; Houk, 1943; Kithil, 1915; Mertie, 1953;

Pratt, 1916; Santmyers, 1930; Schaller, 1922; Sterrett, 1907 


\section{Monazite--Continued}

History: Kithil, 1915; Mertie, 1953; Nitze, 1895a, 1895b; Santmyers, 1930

Mineralogy: Nitze。1895a。1895b; Pratt and Sterrett, 1910

Nomenclature: Nitze, $1895 \mathrm{a}, 1895 \mathrm{~b}$

Occurrences : Abbott, 1954; Congresșional Documents, 1953; Cooley, 1953; Day and Richards, 1906 ; Kithil, 1915; Lindgren, 1898; Mertié, 1949, 1953; Moxham, 1954; Nitze, 1895a, 1895b; Olșon and others, 1954; Parks, 1949; Pratt, 1916, 1917; Pratt and Stertett, 1910; Santmyers Sloan, 1908; Staley, 1948; Staley and Browning, 1949; Sterrett, 1907, 1911; Trites and Tooker, 1953; Anonymous, $1954 \mathrm{~b}$

Origin: Mertie, 1953; Parks, 1949; Schrader, 1910

Price: Carlson,Kaufman, and others, 1953; Carlson, Keiser, and Sargent, 1953; Congressional Documents, 1952, 1953; Roots, 1946

Production: Cooley, 1953; Houk, 1943; Kithil, 1915; Mertie, 1949, 1953; Nitze, 1895a, 1895b; Parks, 1949; Pratt。 1916; Santmyers, 1930; Schaller, 1922; Sterrett, 1907, 1911; Anonymous, $1949 a, 1949 b, 1950 a, 1952 b, 1954 b, 1954 c$

Purchasers: Carlson, Kaufman, and others, 1953; Carlson, Keiser, and Sargent, 1953; Houk, 1943; Roots, 1946

Resources: Congressional Documents, 1953; Kithil, 1915; Parks, 1949; Staley, 1948

Source areas: Mertie, 1953; Sloan, 1908

Treatment: Argall, 1954; Congressional Docúments, 1953; Kithil, 1915; Kremers, 1949; Levy, 1915; Nitze。1895a, 1895b, Parks, 1949; Pratt, 1916; Pratt and Sterrett, 1910; Roots, 1946; Staley and Browning, 1949; Sterrett, 1907, 1911; Anonymous, 1949b

Uses: Argall, 1954; Carlson, Kaüfman, and others, 1953; Carlson, Keiser, and Sargent, 1953; Congressional Documents, 1953; Houk, 1943; Mertie, 1949; Nitze, 1895a, 1895b; Pratt, 1917; Pratt and Sterrett, 1910; Staley, 1948; Roots, 1946

World review: Carlson, Kaufman, and others, 1953; Carlson, Keiser, and Sargent, 1953 
Montana: Carlson, Kaufman, and others, 1953; Carlson, Keiser,and Sargent, 1953; Cooper, 1953, 1954

Beaverhead County

Lemhi Pass district: Trires and Tooker, 1953

Deer Creek district: Trites and Tooker, 1953

Neodymium: Hess, 1908, Petar, 1935

Nernst lamp: Atkinson, 1910; Hess, 1908

New Mexico: Cooper, 1953, 1954

Lincoln County

Gallinas district: Congressional Documents, 1952; Glass and Smalley, 1945; Soule, 1946;

Anonymous, 1952a

North Carolina: Carlson, Kaufman, and others, 1953; Carlson, Keiser, and Sargent, 1953; Mertie, 1953;

Nitze, 1895a; : Pratt, 1916, 1917; Pratt and Sterrett, 1910; Sterrett, 1907; Anonymous, 1954a, 1954d Henderson County: Atkinson, 1910

Oregon: Cooper, 1953, 1954; Day and Richards, 1906

Pegmatite: Hess, 1908; Trites and Tooker, 1953

Placers: Bates and Wedow, 1953; Cannon, 1950; Carlson, Kaufman, and others, 1953; Day and Richards, 1906;

Gillson, 1949; Kithil, 1915; Lindgren, 1898; Mertie 1953; Moxham, 1954; Nitze, 1895a, 1895b;

Parks, 1949; Pratt, 1916, 1917; Pratt and Sterrett, 1910; Roots, 1946; Sçhrader, 1910; Sloan, 1908; Sta Tey, IC ‘8;

Staley and Browning, 1949; Sterrett, 1907, 1911; West and Matzko, 1953; White and Stevens, 1953;

Anonymous, 1949a, 1949b, 1950a, 1954a, 1954b, 1954c, 1954d, 1954e

Polycrase: Hess, 1908

Praseodymium: Hess, 1908; Petar。 1935

Rare earths: Carlson, Keiset, and Sargent, 1953; Cooper, 1953, 1954; Levy, 1915; Petar, 1935; Pratt, 1916;

Roots, 1946; Schaller, 1922

Analyses: Murata and others, 1953; Pratt, 1916 ,

Chemistry: Levy, 1915: Murata and others, 1953; Petar, 1935; Pratt, 1916 
Rare earths--Continued

Consumption: Roots, 1946

Economics: Congressional Documents, 1953; Mertie, 1949

Foreign trade: Congressional Documents, 1953; Petar, 1935; Santmyers, 1930; Schaller, 1922

History: Petar, 1935

Industry: Congressional Documents, 1953; Kremers, 1949; Petar, 1935; Schaller, 1922

Mineralogy: Frondel and Fleischer, 1952; Levy, 1915; Petar, 1935

Occurrence: Abbotr, 1954; Bates and Wedow, 1953; Congressional Documents, 1952 , 1953 ;

Cooley, 1953; Cooper, 1953, 1954; Glass and Smalley, 1945; Hess, 1908; Levy, 1915;

Mertie, 1949; Olson and others, 1954; Petar, 1935; Pratt, 1916; Santmyers, 1930; Schaller, 1922;

Sharp and Pray, 1952; Soule, 1946; Trites and Tooker, 1953; Anonymous, 1950b, 1952a, 1952c

Prices: Carlson, Keiser, and Sargent, 1953; Congressional Documents, 1953; Petar, 1935

Producers: Carlson, Keiser and Sargent, 1953; Petar, 1935

Production: Atkinson, 1910; Congressional Documents, 1952; Cooley, 1953; Hess, 1908;

Mertie, 1949; Roots, 11946; Santmyers; 1930; Schaller, 1922; Anonymous, 1949b, $1952 a$.

$1954 \mathrm{~b}, 1954 \mathrm{e}$

Purchasers: Petar, 1935; Roots, 1946

Resources: Congressional Documents, 1953

Substitutes: Congressional Documents, 1953

Technology: Congressional Documents, 1953; Kremers, 1949; Levy, 1915; Roots, 1946; Anonymous. $1949 \mathrm{~b}$

Uses: Atkinson, 1910; Carlson, Keiser,and Sargent, 1953; Congressional Documents, 1952, 1953;

Kremers, 1949; Levy. 1915; Mertie, 1949; Petar, 1935; Roots, 1946; Sharp and Pray. 1952

Saprolite: Mertie; 1953; Pratt, 1916; Sterrett, 1907

South Carolina: Carlson, Kaufman, and orhers, 1953; Carlson, Keiser, and Sargent, 1953; Mertie. 1953;

Pratt and Sterrett, 1910; Sloan, 1908; Sterrett, 1907; Anonymous, 1954d 
Texas:

\section{Llano County}

Baringer Hill: Atkinson, 1910; Hess, 1908

Thorianite: Roots, 1946; Schaller, 1922; White and Stevens, 1953

Thorite: Christman, and others, 1953; Olson and others, 1954; Roots, 1946; Schaller, 1922; West and Matzko, 1953

Thorium: Cooper, 1953, 1954; Kithil. 1915; Mertie, 1953; Pratt, 1916; Roots, 1946; Santmyers, 1930; Schaller, 1922

Consumption: Roots, 1946

Distribution: Parks, 1949; Santmyers, 1930

Economics: Mertie, 1949

Foreign trade: Santmyers, 1930; Schaller, 1922

Marketing: Roots, 1946

Milling: Roots, 1946

Mineralogy: Bates and Wedow, 1953; Frondel and Fleischer, 1952; Parks, 1949

Mining: Roots, 1946

Occurrences: Abbott, 1954; Bates and Wedow, 1953; Burbank and Pierson, 1953; Christman, and others, 1953; Congressional Documents, 1952; Cooper, 1953, 1954; Mertie, 1949; Moxham, 1954;

Olson and Wallace, 1955; Parks, 1949; Santmyers, 1930; Schaller, 1922; Sharp and Pray, 1952;

Sterrett, 1911; Trites and Tooker, 1953; White and Stevens, 1953; Anonymous, 1952c, 1954a, $1954 d$

Production: Congressional Documents, 1952; Mertie, 1949; Roots, 1946; Santmyers, 1930; Schaller, 1922; Anonymous, 1954b, 1954c, $1954 \mathrm{e}$

Purchasers: Roots, 1946

Resources: Congressional Documents , 1953; Parks, 1949

Uses: Congressional Documents, 1952, 1953; Mertie, 1949; Parks, 1949; U. S. Atomic Energy Commission, 1954 
Tin: Bates and Wedow, 1953; Moxham, 1954

Titanium: See ilmenite

Tuscaloosa formation: Mertie, 1953

Uganda: Carlson, Keiser and Sargent, 1953

Union of South Africa: Carlson, Keiser and Sargent, 1953

U. S. Bureau of Mines: Carlson, Kaufman, and others, 1953; Carlson, Keiser,and Sargent, 1953;

Congressional Documents, 1953; Anonymous, 1954e

Uranium: Mertie, 1953; Trites and Tooker, 1953; Anonymous, 1950b, 1954c, 1954e

Uranothorianike; Bates and Wedow, 1953; West and Matzko, 1953

Uranothorite : White and Stevens, 1953

Vein deposits: Bates and Wedow, 1953; Burbank and Pierson, 1953; Carlson, Kaufman, and others, 1953;

Carlson, Keisę̧ and Sargent, 1953; Christman and others, 1953, Cooley, 1953; Glass and Smalley, 1945;

Olson and others, 1954 ; Roots, 1946; Sharp and Pray, 1952; Soule, 1946; Trites and Tooker, 1953;

White and Stevens, 1953; Anonymous, 1952a, 1952c

Virginia: Mertie, 1953; Anonymous, 1954a

Wyoming: Carlson, Keiser and Sargent, 1953; Cooper, 1953, 1954

Crook County

Bear Lodge Mountains district: Anonymous, 1950b

Sundance: Anonymous, 1950b

Xenotime: Roots, 1946

Yttrium: Atkinson, 1910; Hess, 1908; Pratt, 1916

Zircohium: Hess, 1908; Moxham, 1954; Pratt, 1916; Santmyers, 1930; Schaller, 1922; Staley, 1948;

Staley and Browning, 1949; Sterrett, 1911 